\title{
Least Prefernce of High Sulfide Content Shampoos for Rural Consumers
}

\author{
D. Venkatrama Raju J. Kannan.
}

\begin{abstract}
The study is about buyer behaviour in selecting a shampoo brand. Through the pilot study it has been found that Clinic Plus, Head \& Shoulder, Pantene, Sun silks, Clinic All Clear, Himalaya, Velvette, Meera and Shika are the brands largely used. Hence they were taken up for the study.

Keywords :Consumers,Purchasing behavior,Shampoo .
\end{abstract}

\section{INTRODUCTION}

Shampoos are a highly priority area for major players such as Hindustan Lever. Shampoos are the cleaning agents to clean the hairs. Shampoos are used for other purposes like to get rid from dandruff, to have shine, to make the hair healthier, to straighten the curly hair, to avoid the two ends hairs etc. At a time when most FMCG (fast moving consumer goods) segments are inching along, personal items are seen as the harbinger of prosperity. And hair care items are the fastest growing category in specific brands. Although toilet soaps have achieved depletion, there is a huge potential for shampoos to enter Indian households.[1]-[5]

\section{STATEMENT OF THE PROBLEM}

Today's women are engaged in various activities like studies, job etc. the time that women spend on themselves have come down. Along with these official tensions, women have to take care of their family life also.

Traditional methods are the one usually used to clean and condition the hair. But the preparation consumed more time and attention. As today's women lack time for these activities, they want "Ready-to-use" items. Factors like type of hair do have its contribution in selecting the brand of shampoo.

It is important to study the factors influencing the purchase decision as the market for the shampoo industry is developing immensely. In this some local and foreign brands are emerging as the competitors. Each company should do such surveys to know their market potential, and to know the ways to improve the market share. [6]-[10]

\section{OBJECTIVES}

- To identify the brand preference among shampoos.

- To identify the market leader.

- To trace the reasons for shifting to another brand.

- To understand the usage pattern.

Revised Manuscript Received on December 30, 2019.

D. Venkatrama Raju , Professor \& Head, Department Of Science \& Humanities,Bharath Institution Of Higher Education And Research TamilNadu,India Email prof.dvraju@gmail.com

J. Kannan, Associate Professor, Department Of Science \& Humanities,Bharath Institution Of Higher Education And Research TamilNadu,India Email sjkannan1986@gmail.com
- To identify the factors that motivates the consumers to buy the product.

\section{LIMITATIONS}

- The study is confined only to Rural Population.

- The data collected from the respondents is qualitative in nature i.e. views, opinions, perception etc. These factors may be changed from tie to time.

- Time is the major constraint, analysis of data consumed more time.

\section{RESEARCH METHDOLOGY}

The experimental design for the Persecute Study was systematic and carried out in accordance with the goals set out below.

\section{A.Research}

Research is a method in which the investigator wants to find the final result for a given problem and thus the solution can aid in the potential course of action. As per Redman and Mory, research is described as a "deliberate effort to gain new insights"

\section{B.Research design}

Research design is the arrangement of conditions for collection and analysis of data in a manner that aims to combine relevance to the research purpose with economy in procedure. Exploratory research seeks to discover new relationships. There are drawn from ideas developed in the previous research studies or drawn from theory. Conclusive research helps executives to choose among the various course of action. A descriptive study attempts to obtain a complete and accurate descriptive of a situation. [11]-[14]

Data sources

\section{C.Secondary data}

Secondary data consists of information that already exists some where having been collected for some other purpose. The secondary data for this dissertation has been collected from various books and websites.

\section{D.Primary data}

Primary data consists of original information collected for specific purpose. The primary data for this research study was collected through a direct survey. To obtain this primary data a well structured questionnaire was prepared by the researcher.

\section{E.Population}

Population or universe can be defined as the complete set of items that are of interest in any particular situation. Population for this study is shampoo users.

Sample

Sample denotes only a part of the universe, which is studied, and 
conclusions drawn on the basis of the entire universe.

Process of sampling involves

\section{Selecting the sample \\ Collecting data fro the sample}

Marking an inference from the population

Sample method is less time consuming. Cost as a whole is less as only a part of the universe is studied. Results are more reliable.

\section{F.Sample unit}

Sample unit tells, 'who is to be surveyed?' for this market study.

Female shampoo users were surveyed for this study.

Judgment sampling,

Convenience sampling, and

Quota sampling.[15]-[19]

\section{FINDINGS}

From the sample of two hundred respondents 113 has Normal, 73 has Dry, and 14 has Oily hair.

Antidandruff shampoos are used by 80 , with conditioners are used by 137 , Ordinary shampoos are used by 117

Shampoos mostly Used are Clinic plus (156 respondents), Head \& Shoulders (57 respondents), Pantene (82 respondents), Sun silk (107 respondents), Clinic all clear (63 respondents)

Clinic plus (109 respondents), H\& S (39 respondents), Pantene (93 respondents), Sun silk (69 respondents), and Clinic all clear (32 respondents) are selected as the favourite shampoos

Source of information is through advertisements (180 respondents), Friends (80 respondents), Shop keepers (54 respondents), and Beauticians (79 respondents)

Respondents buy from Petty shops (99 respondents), Provisional stores (159 respondents) and Super markets (130 respondents)

On non availability of the preferred shampoo on a shop respondents, Try another brand (23 respondents), Go to another shop159 (respondents), and Postpone the purchase 18 (respondents)

Sachets are used by 131 respondents, Containers are used by 50 respondents, Bigger containers are used by 18 respondents,

136 respondents stock Shampoos at their home.

48 respondents Switch brands often.

Reasons for switching brands are Influence of friends, Influence of advertisements, Poor quality.

Most of the respondents have been using their current brand of shampoo for one year. Many are using for past two years, and some are using for last 6 months.
Necessary feature in a shampoo brand are Price (131 respondents) ,Colour (97 respondents), Lather 130,Less consumption (105 respondents),Fragrance (134 respondents),Conditioning (109 respondents)

Most of the respondents Shampoo their hair, once in a week (110 respondents), 57 respondents Shampoo their hair twice a week, 33 respondents Shampoo their hair once in fortnight.

It has been felt that there is a limited choice of shampoos in India (136 respondents), Shampoos should be priced even low (50 respondents) and much difference is not found in shampoos (130 respondents)

Most of the respondents say that when it comes to advertisements, Language should be simple, it should be colorful, it should create awareness, and its uses should be emphasized

Broad casting media is mostly watched by the respondents.

Some of the respondents read newspapers (The Hindu and The New Indian express)

Sun TV, Star Vijay, and KTV are the channels mostly watched.

Radio Mirchi and Suryan FM are the frequencies heard in Radio.

Most of the respondents say that they get satisfaction using their current brand; some say that they get value of money, praise from friends, social acceptability and recognition.

Offers do influence the purchase decisions of the respondents.

Mostly self experience influence respondents next comes advertisements.

\section{H.Suggestions}

1. Researches has to be conducted more to know the changes in the buyer behaviour.

2. Research and development has to be conducted to make a product to meet all the requirements i.e. a Shampoo with antidandruff, conditioning agents who would be even herbal based.

3. Shampoos should not lead to hair fall and should have hair fall controlling agent.

4. Brands should be made available in various outlets.

5. In India, we have only limited choice of Shampoo. Companies should come with new brands.[20]-[25]

6 . In general there is water scarcity; Brands which makes the user use a lesser quantity of water will be welcomed.

7. The advertisements should be appealing.

8. False promising should not be made in advertisements.

9. Broadcasting media, being the most noticed media has to be effectively used for advertising.

10. Advertisements have to be given in the regional channels which reach more than the national channels.

11. As more respondents say that they get influenced through self experience, samples can be issued to the shampoo users. 
12. Clinic plus is the brand most preferred. HLL should work on it to keep up its market.

13. Offers and discounts are those looked for; hence such announcements will lead to movement of stock and as a strategy against the competitors to block the future sales of competitors' brands.

\section{CONCLUSION}

Still authentic and orthodox way of Herbal powder made with soup ness and hibiscus are used for cleaning and nourishing the hairs.

Most of the respondents use shampoos once in a week.

Most of the female have Normal and dry hair.

Most of the respondents are using Clinic Plus.

Respondents switch to other brands because of better brand availability.

Offers and discounts do have impact in the purchase decision of most of the buyers.

Friends, Neighbors, Advertisement, and Self Experience influence the purchase decisions.

\section{REFERENCES}

1. Vasanthi, S. \& Rabiyathul Basariya, S. 2019, "Influence of value analysis and cross training in industry", International Journal of Engineering and Advanced Technology, vol. 8, no. 6, pp. 1810-1811.

2. Velvizhi, R., Sri Gowtham, S. \& Jeya Priya, D. 2019, "Examination of early feedbacks for effective product retailing on E-commerce websites", International Journal of Engineering and Advanced Technology, vol. 8, no. 6 Special Issue 2, pp. 703-706.

3. Anuradha, C., Pothumani, S. \& Kavitha, R. 2019, "A novel method towards E-commerce", International Journal of Engineering and Advanced Technology, vol. 8, no. 6 Special Issue 2, pp. 535-538.

4. Thomas, J. \& Rabiyathul Basariya, S. 2019, "A study on the issues of financial ratio analysis", Indian Journal of Public Health Research and Development, vol. 10, no. 3, pp. 1079-1081.

5. Ramachandran, S. \& Rabiyathul Basariya, S. 2019, "Online marketing - study on customer satisfaction and relationship", Indian Journal of Public Health Research and Development, vol. 10, no. 3, pp. 1072-1078.

6. Priya, R., Vinothini, G. \& Cor Jesu, C.D. 2019, "The mentor-protégé relationship for professional growth", Journal of Advanced Research in Dynamical and Control Systems, vol. 11, no. 9 Special Issue, pp. 1110-1119.

7. Jannifer Rani, N., Bina Pani, S. \& Nimisha, N.S. 2019, "A study on money back polices available in LIC", Journal of Advanced Research in Dynamical and Control Systems, vol. 11, no. 9 Special Issue, pp. 833-839.

8. Saillaja, V., Jhansi Rani, K. \& Catherine, R. 2019, "Global marketing management planning and organization", Journal of Advanced Research in Dynamical and Control Systems, vol. 11, no. 9 Special Issue, pp. 489-493.

9. Saillaja, V., Jhansi Rani, K. \& Catherine, R. 2019, "The new phase of marketing information system", Journal of Advanced Research in Dynamical and Control Systems, vol. 11, no. 9 Special Issue, pp. 482-488.

10. Thoufiqulla \& Raju, D.V. 2019, "Perception of indian investor towards investment in mutual funds with special reference to mip funds", Journal of Advanced Research in Dynamical and Control Systems, vol. 11, no. 5, pp. 177-183.

11. Jasmine, K.R.M. \& Basariya, S.R. 2018, "A study on the customers benefits on mutual funds", International Journal of Civil Engineering and Technology, vol. 9, no. 4, pp. 45-48.

12. Vasanthi, S. \& Basariya, S.R. 2019, "Pros and cons of on the job training versus off the job training", International Journal of Scientific and Technology Research, vol. 8, no. 10, pp. 671-674.
13. Pavithra, J. \& Ganesan, M. 2016, "A study on awareness and impact of micro-financial schemes", International Journal of Applied Business and Economic Research, vol. 14, no. 8, pp. 5449-5460.

14. Pavithra, J., Dilli Babu, P. \& Ambuli, T.V. 2014, "A study on budgetary control at Maruti Service Masters, Chennai", International Journal of Applied Business and Economic Research, vol. 12, no. 2, pp. 151-161

15. Gunaraja, T.M. \& Venkatrama Raju, D. 2018, "Determining factors of organisational climate with reference to leadership styles", International Journal of Mechanical Engineering and Technology, vol. 9, no. 9, pp. 1327-1332.

16. Gunaraja, T.M. \& Venkatrama Raju, D. 2018, "The role of job satisfaction and training of employees in determining organisational climate of a selected industry", International Journal of Civil Engineering and Technology, vol. 9, no. 8, pp. 1266-1269.

17. Aarathy, T.S. \& Raju, D.V. 2018, "Performance appraisal and its effects on employees with respect to it sector in Chennai city", International Journal of Civil Engineering and Technology, vol. 9, no. 6, pp. 1535-1538.

18. Aarathy, T.S. \& Raju, D.V. 2018, "Employee perception towards performance appraisal system in IT sector", International Journal of Mechanical Engineering and Technology, vol. 9, no. 5, pp. 131-135.

19. Porselvi, W., Jublee, D. \& Sivanesan, G. 2018, "A study on factors influencing adoption of technology and innovation in banking industry, tamilnadu, India", International Journal of Mechanical Engineering and Technology, vol. 9, no. 5, pp. 789-800.

20. Akessa, G.M. and Dhufera, A.G., 2015. Factors That Influences Students Academic Performance: A Case of Rift Valley University, Jimma, Ethiopia. Journal of Education and Practice, 6(22), pp.55-63.

21. Miller, G. and Shih, C.C., 1999. A faculty assessment of the academic rigor of on-and off-campus courses in agriculture. Journal of Agricultural Education, 40, pp.57-65.

22. Tsinidou, M., Gerogiannis, V. and Fitsilis, P., 2010. Evaluation of the factors that determine quality in higher education: an empirical study. Quality Assurance in education, 18(3), pp.227-244.

23. Farooq, M.S., Chaudhry, A.H., Shafiq, M. and Berhanu, G., 2011. Factors affecting students' quality of academic performance: a case of secondary school level. Journal of quality and technology management, 7(2), pp.1-14.

24. Fitsilis, P., Gerogiannis, V. and Anthopoulos, L., 2014. Ontologies for software project management: a review. Journal of Software Engineering and Applications, 7(13), p.1096.

25. Adams, J.D. and Jaffe, A.B., 1996. Bounding the effects of R\&D: an investigation using matched establishment-firm data(No. w5544). National bureau of economic research.

\section{AUTHORS PROFILE}

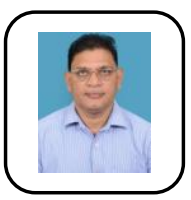

D. Venkatrama Raju , Professor \& Head, Department Of Science \& Humanities,Bharath Institution Of Higher Education And Research TamilNadu,India

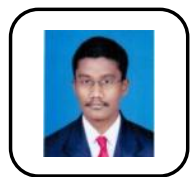

J. Kannan, Associate Professor, Department Of Science \& Humanities,Bharath Institution Of Higher Education And Research TamilNadu,India 